\title{
Multiple Leukocyte Abnormalities in Chronic Granulomatous Disease: A Familial Study
}

\author{
WILLIAM D), RUTLNBERG, MIEI (. YANG, E. BRIAN DOBERSTYN, ANI) \\ JOSEPH A. BELLANTI' '+!' \\ Departme'nts of Pediatrics and Microbiology, Georgetown University School of Medicine. Washington, I).C., USA
}

\begin{abstract}
Summary
A variety of leukocyte enzyme activities were studied in an 11 year-old female with chronic granulomatous disease (CGD) and several members of her family. Leukocyte glucose-(6-phosphate dehydrogenase (G-6-PI)) activity was $17 \mathrm{mmol} / \mathrm{min} / \mathrm{mg} \mathrm{protein}$ in the patient; two brothers with symptoms of recurrent bacterial infections have G-(6-PI) activities of 58 and $37 \mathrm{nmol} / \mathrm{min} / \mathrm{mg}$ protein; the activites of this enzyme in both parents, maternal grandmother, and one additional brother were within normal limits. Storage at $4^{\circ}$ or heating at $37^{\circ}$ over a 120 -min period revealed a marked lability of G-6-PD activity in the patient's cells which could not be stabilized by the addition of $N A D P$ and 2-mercaptoethanol; this lability was not seen in other family members tested. Activities of leukocyte glutathione reductase were reduced in both parents and the two affected male siblings with values of $18,23,23$, and $24 \mathrm{mmol} / \mathrm{min} / \mathrm{mg}$ protein, respectively. Activities of leukocyte glutathione peroxidase were reduced in all of the immediate family members tested, with values ranging from 11.2 to $4.3 \mathrm{mmol} / \mathrm{min} / \mathrm{mg}$ protein; the activity of this enzyme in the patient was 38.5 . Leukocyte $N A D P$ content in the patient, father, and two affected male siblings were $16.5,23.4$, 22.2 , and $28.2 \mathrm{nmol} / 15 \mathrm{~min} / 10^{7}$ leukocytes, respectively.
\end{abstract}

\section{Speculation}

Chronic granulomatous disease represents a heterogenous collection of leukocyte enzymatic abnormalities which result in a clinical picture of recurrent bacterial infection. The final common pathway in the pathogenesis of the disorder derives from defective $\mathrm{H}_{2}$ (O) production owing to a variety of enzymatic abnormalities within or linked to the hexose monophosphate shunt (HNI). The studies of the kindred in the present report lend further support for the central role of NADP as a controlling mechanism of normal leukocyte bactericidal function.

The clinical entity, (GD), is a disorder of neutrophil function in which the leukocytes of affected patients can phagocytose bacteria normally but have impaired intracellular killing of certain bacteria (20, 29). Metabolically, leukocytes of affected patients fail to show the normal stimulation of respiratory activity, increased $O_{2}$ consumption, oxidation of glucose through the HMP, and generation of hydrogen peroxide ( $\left.\mathrm{H}_{2} \mathrm{O}_{2}\right)$, events associated with normal bactericidal action $(3,17)$. There is a concomitant failure of these affected cells to change the oxidized colorless form of nitroblue tetrazolium (NBT) dye to its blue reduced counterpart during phagocytosis, providing a useful diagnostic test for the disease $(4,25,27)$.

Originally described in males as a syndrome with an X-linked mode of transmission $(9,10,34)$, CGD has been described in male and female patients with an autosomal recessive mode of inheritance $(18,24,28)$. A myriad of leukocyte enzyme deficiencies have been described. The entity has been associated with G-6-PD lability (6) or deficiency (1) in males, with glutathione peroxidase deficiency in females (18) and males (24), with diminished NADH oxidase (2) and NADPH oxidase activity (16), and with decreased superoxide production (13). In the current report, a family is studied in which several members manifest recurrent infections and allergic discase, and who display abnormal bactericidal function, impaired reduction of NBT dye, and a variety of leukocytic enzyme defects.

\section{CASE REPORT}

$\mathrm{KL}$ is an 11-year-old Caucasian female referred to Georgetown University Hospital for evaluation of chronic recurrent skin and respiratory infections which began at 6 months of age. Within the first 2 years of life, a series of recurrent throat infections occurred which were treated sucesssully with antibiotics. At 6 months of age, pneumonia occurred which did not require hospitalization. The patient developed rubeola at 18 months of age concurrently with her siblings. Shortly thereafter. she contracted varicella and the pox lesions became heavily secondarily infected with bacteria. These were especially prominent on the skin of the eyelids and perineum. Although decreased in frequency, the recurrent throat infections have continued to the present, and over the past 3 years, recurrent skin infections have also appeared. These have consisted primarily of vesiculopustular lesions localized to the skin of the perioral regions and legs. Two years ago, the patient developed pharyngitis and an abscessed cervical lymph node which required surgical drainage. After a 10-day course of parenteral penicillin therapy, she was placed on daily prophylactic oxacillin for approximately 1 year which significantly lessened the frequency and severity of the recurrent skin infections.

The patient was a product of a full term normal pregnancy. Immunizations, including smallpox vaccination, were performed without complication. Two weeks after rubella immunization, however, rash, maliase and arthralgia occurred, which subsided within 3-5 days. She has had contact dermatitis dec to poison ivy and poison oak.

Physical examination revealed an alert, cooperative, well developed 11-year-old Caucasian female with fair skin and red hair. Several scars were present on the skin at the sites of previous skin infections and surgical procedures. The spleen tip was palpable $1-2 \mathrm{~cm}$ below the left costal margin. A grade l-II/ VI innocent systolic murmur was heard along the left sternal border.

Complete blood count revealed a hematocrit of $37 \%$ and a total leukocyte count of 7.500 cells $/ \mathrm{mm}^{3}$ with $30 \%$ polymorphonuclear leukocytes, $64 \%$ lymphocytes, $2 \%$ monocytes, and $4 \%$ eosinophils; cosinophilia was also noted on several subsequent examinations. Urinalysis was within normal limits. Protein electrophoresis, immunoclectrophoresis, and chemotactic studies (performed by Dr. Peter A. Ward) were all normal. A Mono spot test (Ortho) and febrile agglutinins were negative. Stools 
were negative for ova and parasites, and blood urea nitrogen, creatinine, blood sugar, alkaline phosphatase, serum glutamicoxaloacetic and serum glutamic-pyruvic transaminases, and lactate dehydrogenase were all within normal limits. At the time of referral, Staphylococcus epidermidis. Streptococeus viridans, and group $D \beta$-hemolytic streptococcus were recovered from infected skin lesions. Tests of delayed skin hypersensitivity to mumps virus were positive but negative to tubereulin, coccidioidin, blastomycin, and histoplasmin.

\section{MATERIALS AND METHODS}

\section{SUBJECTS}

An 11 -year-old female and her family were studied at Georgetown University Hospital (Table 1). Age-adjusted and adult subjects were included as control subjects for the biochemical and bactericidal studies described below.

\section{PREPARATION OF LEUKOCYTE SUSPENSION}

Methods for the preparation of a relatively rich suspension of granulocytes were those described by Baehner and Nathan (4) with minor modification, as previously described (6). Differential count of this fluid revealed values consistently in excess of $90 \%$ polymorphonuclear leukocytes.

\section{QUANTITATIVE NITROBLUE TETRAZOLIUM TEST}

The quantitative NBT test was performed by the method of Bachner and Nathan (4), results being expressed as the change in optical density phagocytosing values for $2.5 \times 10^{6}$ cells for 15 min at $37^{\circ}$.

\section{BACTIERICIDAL TEST}

The bactericidal assay was performed by the method of Quie 't al. (29) using Staphylococcus aureus as a test strain. The results were expressed as the pereentage of viable bacteria remaining after $120 \mathrm{~min}$ of incubation with polymorphonuclear leukocytes.

\section{NEUTROPHIL ENZYME DETFRMINATIONS}

Cell homogenates were prepared from frozen crude cell suspensions by methods described previously (6). The supernatants were analyzed for protein content (23) and the enzymatic assalys were performed as described below.

The activities of G-6-PD, 6-phosphogluconate dehydrogenase (6-PGD), and NADP-specific glutathione reductase in white cell lysates were determined by the method of Richterich (31). Glutathione peroxidase activity was determined by the method of Paglia and Valentine (26). The results of all leukocyte enzyme activities are reported as nanomoles per min per mg protein at $25^{\circ}$. Leukocyte NADP content was assayed according to the procedure of Klingenberg (22) and is reported as nanomoles per 15 min per $10^{7}$ leukocytes. The optical densities were determined with a spectrophotometer using $1-\mathrm{cm}$ cuvettes that were maintained at $25^{\circ}$ by means of a circulating water bath.

\section{G-6-PD LABILITY AND MIXING EXPERIMENTS}

Experiments were performed to determine the effect of stabilizing agents on G-6-PD activity during serial incubation periods at $37^{\circ}$ according to methods previously described (6). Leukocyte homogenates, prepared from leukocytes frozen at $-70^{\circ}$, were tested both in the absence and presence of $6 \mu \mathrm{M}$ NADP plus 25 $\mathrm{mM} 2$-mercaptocthanol (2-ME) at $0,30,60$, and $120 \mathrm{~min}$ of incubation at $37^{\circ}$ (Table 3, Fig. 2). In order to assess the possibility of a G-6-PD enzyme inhibitor, leukocyte homogenates from the patient and a normal control subject were mixed in equal proportions and lability studies were performed in accordance with the methods just described. The results were compared with the lability studies of the patient's and the control's cells when tested individually (Fig. 3).

\section{RESULTS}

\section{CLINICAL DATA}

Clinical data on the patient's family are given in Table 1 and according to the pedigree shown in Figure 1. It can be seen that, of the 17 members for whom information was available, infections were seen in the maternal greatgrandmother (II-2), the

Table 1. Clinical data on family members of patient $K L$

\begin{tabular}{|c|c|c|c|c|c|c|}
\hline $\begin{array}{l}\text { Family } \\
\text { member }\end{array}$ & $\begin{array}{l}\text { No. in pe- } \\
\text { digree }\end{array}$ & Relation to proband & Sex & $\begin{array}{l}\text { Age, } \\
\text { years }\end{array}$ & $\begin{array}{l}\text { Age at onset } \\
\text { of infections, } \\
\text { years }\end{array}$ & Clinical symptomatology \\
\hline$G G M$ & $1-1$ & Maternal greatgrandmother & $\mathrm{F}$ & Dicd 72 & Unknown & Skin infections, chronic bronchitis \\
\hline$G G F$ & $\mathrm{I}-2$ & Maternal greatgrandfather & M & Died 82 & 0 & Healthy \\
\hline$R A$ & II-1 & Maternal grandfather & $M$ & 54 & 0 & Healthy \\
\hline$K C$ & II-2 & Maternal grandmother & $\mathrm{F}$ & 54 & 44 & $\begin{array}{l}\text { Cystitis, rash, repeated bacterial upper respira- } \\
\text { tory infections }\end{array}$ \\
\hline IC & $11-3$ & Maternal stepgrandfather & $\mathrm{M}$ & 56 & () & Healthy \\
\hline$J E$ & III-1 & Uncle by marriage & $M$ & 28 & 0 & Rheumatic fever, healthy \\
\hline$S E$ & III-2 & Maternal aunt & $\mathrm{F}$ & 27 & 0 & Chronic sinusitis, multiple allergies \\
\hline$N L$ & III -3 & Mother & $\mathrm{F}$ & 32 & () & $\begin{array}{l}\text { Eczema, recurrent periodontal and urinary tract } \\
\text { infections }\end{array}$ \\
\hline WI & $111-4$ & Father & $M$ & 3.3 & () & Allergies since childhood \\
\hline$C^{\prime} C^{\prime}$ & III-5 & Maternal step-atunt & $\mathrm{F}$ & Dicd 21 & $6 / 12$ & Repeated pharyngotonsillitis, pancytopenia \\
\hline$M C$ & III-6 & Maternal step-uncle & M1 & 17 & $14 / 12$ & $\begin{array}{l}\text { Repeated bacterial pneumonias diagnosed as hy- } \\
\text { pogammaglobulinemia and treated with } \gamma \text {-glob- } \\
\text { ulin, age } 2-6 \text { years }\end{array}$ \\
\hline$J E$ & IV-1 & First cousin & M & 3 & () & Milk allergy, sinusitis \\
\hline$M L E$ & IV -2 & First cousin & M & 2 & () & Milk allergy, sinusitis, hordeolum 6 mo-1 year \\
\hline$B L$ & IV -3 & Brother & M & 14 & 2 & $\begin{array}{l}\text { Asthma, recurrent pharyngotonsillitis and otitis } \\
\text { media, urinary tract infections, boils on skin, } \\
\text { granuloma removed in } 1967 \text { from arm }\end{array}$ \\
\hline$D L$ & IV-4 & Brother & $M$ & 12 & 1 & Repeated pharyngotonsillitis and otitis media (see \\
\hline KL & IV-5 & Proband & $\mathrm{F}$ & 10 & $6 / 12$ & text) \\
\hline$M L$ & IV-6 & Brother & $M$ & 4 & 0 & $\begin{array}{l}\text { Atopic eczema, milk allergy, no recurrent infec- } \\
\text { tions }\end{array}$ \\
\hline
\end{tabular}


mother (III-3), and two siblings (IV-3 and IV-4). A strong history of allergic discase was obtained in several family members (II-2, III-2, III-3, III-4, IV-1, IV-2, IV-3, IV-6). Although a childhood history of hypogammaglobulinemia was obtained in a maternal uncle (III-6), tests of this individual's serum immunoglobulin levels were found to be within normal limits.

\section{NBT ANI) BACTHERICIDAL TESTS}

The results of the yuantitative NBT and bactericidal lests are given in Table 2. It can be seen that all members of the immediate family except for $M L$. clinically the healthiest sibling, had decreased NBT dye reduction when compared with age-adjusted control subjects (7). The abnormality was most marked in the patient, $K L$, and two of her male siblings, $B L$ and $D L$. The patient and several immediate family members also showed imparied bactericidal activity. The defect was most marked in the patient, $K L$, but was also noted in her father, $W L$. and in three male siblings, $B L, D L$, and $M L$, (Table 2).

\section{ENZYMI: STUDIES}

The activities of various leukocyte enzymes and G-6-PD lability are shown in Table 3 and Figure 2. The leukocytes of the

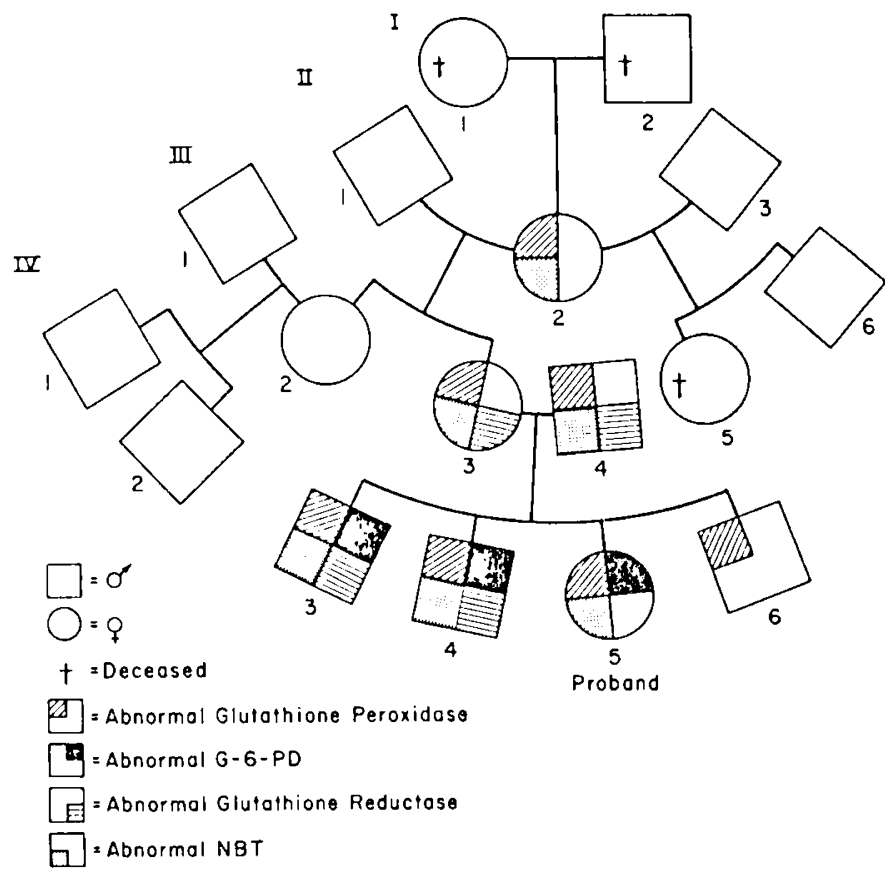

Fig. 1. Pedigree of the paticnt's family. patient and the two male siblings with impaired NBT dye reduetion had significantly reduced G-(1-PI) activity when tested in the absence of NADP and 2-NE at $37^{\circ}$ (Table 3). The results of more extensive investigation of $G-(6-P D)$ lability on the patient and the immediate family are shown in Figure 2. An extreme lability of leukocyte G-(6-PI) was observed in the patient, even when tested in the presence of 2-MIE and NADP. G-(6-PD lability was not detected in any other family members when tested in the presence of those stabilizing agents (Fig. 2).

A separate set of experiments were performed to assess the possibility of an inhibitory factor in the leukocytes of the patient (Fig. 3). The values obtained from a mixture of leukocyte homogenates from the patient and a control subject were intermediate between those values found in either leukocyte homogenate tested individually, indicating that a G-(6-PD) inhibitory factor was not present. No abnormalities in leukocyte (-PGD were detected in any member of the family (Table 3 ). Activities of NADPH-specific glutathione reductase were found to be significantly reduced in the parents and two male siblings, $D L$ and $B L$. Leukocyte glutathione peroxidase activity was significantly decreased in the leukocytes of the patient, her parents, all three male siblings, and the maternal grandmother (Table 3). Finally, leukocyte NADP levels were measured in the patient, several members of her family, and normal control white cells. The average NADP content of normal control leukocytes was $52.0 \pm 6.2(\mathrm{SEM})$. In the family members tested, the patient's cells had the lowest level (16.5), whereas those of her father (23.4) and two male siblings, BL (22.2) and DL (28.2), were intermediate between the patient and control values.

\section{DISCUSSION}

The present report represents the first description of neutrophil dysfunction in a family in association with multiple deficiencies of leukocyte enzymes. Although diminished leukocyte glutathione peroxidase has been observed in both male (24) and female (18) patients with CGD, the unique finding of leukocyte G-6-PD lability together with several leukocyte enzyme defects has not been previously described. Furthermore, the current findings suggest a disorder of neutrophil function with an autosomal recessive mode of inheritance.

Several specific enzymatic deficiencies have been reported in CGD (1). These abnormalities appear to result in an impaired production of endogenous $\mathrm{H}_{2} \mathrm{O}_{2}$. In the normal individual, $\mathrm{H}_{2} \mathrm{O}_{2}$ combines with halide and mveloperoxidase and forms a potent bactericidal complex (20) (Fig. 4). Bachner and Karnovsky (2) demonstrated an NADH oxidase deficiency in four female and one male patient with CGD. In three male patients. Bellanti $e t$ al. (6) found a labile leukocyte G-6-PD enzyme which underwent an accelerated rate of decay under conditions of either storage at $40^{\circ}$ or heating at $38^{\circ}$. A cleficiency in leukocyto

Table 2. Results of nitroblue tetrazolium NBT and bactericidal tests

\begin{tabular}{|c|c|c|c|c|c|c|}
\hline Subject & $\begin{array}{l}\text { Age, } \\
\text { years }\end{array}$ & Relation to proband & $\begin{array}{l}\text { Number in pe- } \\
\text { digree }\end{array}$ & $\mathrm{NBI}^{1}$ & $\begin{array}{c}\text { Normal for age } \pm \\
\text { SI } \vdots\end{array}$ & $\begin{array}{c}\text { Bactericidal ac- } \\
\text { tivity } \% \%\end{array}$ \\
\hline \multicolumn{7}{|l|}{ Immediate family } \\
\hline$K L$ & 11 & Proband & IV -5 & 0.074 & $0.175 \pm 0.024$ & 46 \\
\hline$W L$ & 33 & Father & IIII-4 & 0.111 & $0.206 \pm 0.025$ & 38 \\
\hline$N L$ & 32 & Nother & III -3 & 0.123 & $0.206 \pm 0.025$ & 24 \\
\hline$B L$ & 14 & Brother & IV -3 & 0.088 & $0.175 \pm 0.024$ & 30 \\
\hline$D L$ & 12 & Brother & IV -4 & 0.065 & $0.175 \pm 0.024$ & 35 \\
\hline$M I L$ & 4 & Brother & IV-6 & 0.172 & $0.148 \pm(0.013$ & 35 \\
\hline \multicolumn{7}{|l|}{ Other relatives tested } \\
\hline$K C$ & 54 & Maternal grandmother & $11-2$ & 0.148 & $0.206 \pm 0.025$ & 8 \\
\hline$M C$ & 17 & Matcrnal stcp-uncle & III-6 & 0.175 & $0.175 \pm 0.024$ & 15 \\
\hline$S E$ & 24 & Matcrnal aunt & $111-2$ & 0.108 & $0.175 \pm 0.024$ & 32 \\
\hline Cintrols & & & . & $0.16 !$ & & 26 \\
\hline
\end{tabular}

1 Results are expressed as $\triangle O D$ at $515 \mathrm{~m} \mu / 2.5 \times 10^{\text {ti }}$ leukocytes $/ 15 \mathrm{~min}$ at $37^{\circ}$.

2 Expressed as percentage of viable bacteria remaining after $120 \mathrm{~min}$ of incubation with leukocytes. 
Table 3. Leukocyte enzyme activities ${ }^{1}$

\begin{tabular}{|c|c|c|c|c|c|c|c|}
\hline Subject & Relation to proband & $\begin{array}{l}\text { No. in pe- } \\
\text { digree }\end{array}$ & G-6-PD² & $\begin{array}{c}\text { G-6-PD + } \\
\text { NADP + 2-ME }\end{array}$ & 6-PGD & $\begin{array}{l}\text { GSSG reduc- } \\
\text { tase }\end{array}$ & $\begin{array}{l}\text { GSH peroxi- } \\
\text { dase }\end{array}$ \\
\hline$K L$ & Proband & IV -5 & $17^{3}$ & 107 & 44 & 30 & $38.5^{4}$ \\
\hline$W L$ & Father & III -4 & 99 & 110 & 33 & $18^{3}$ & 41.0 \\
\hline$N L$ & Mother & III-3 & 96 & 112 & 37 & $23^{3}$ & 30.0 \\
\hline$B L$ & Brother & IV-3 & $58^{5}$ & 110 & 45 & $23^{3}$ & $11.2^{3}$ \\
\hline$D L$ & Brother & IV -4 & $37^{3}$ & 106 & 40 & $24^{4}$ & $39.0^{4}$ \\
\hline$M L$ & Brother & IV-6 & 84 & 150 & 57 & 30 & $38.0^{4}$ \\
\hline$K C$ & Maternal grandmother & II -2 & 94 & 154 & 57 & 27 & $43.0^{5}$ \\
\hline$S E$ & Maternal aunt & III-2 & 143 & 212 & 89 & 33 & 75.0 \\
\hline Control & & & $\begin{array}{c}118.0 \pm 4.0 \\
(n=37)\end{array}$ & $\begin{array}{c}129.8 \pm 12.5 \\
(n=4)\end{array}$ & $\begin{array}{c}46.2 \pm 2.1 \\
(n=44)\end{array}$ & $\begin{array}{c}30.9 \pm 0.5 \\
(n=26)\end{array}$ & $\begin{array}{c}82.7 \pm 3.23 \\
(n=26)\end{array}$ \\
\hline
\end{tabular}

${ }^{1}$ Enzyme activity values expressed as nanomoles per $\min$ per $\mathrm{mg}$ protein \pm SE mean. G-6-PD: glucose-6-phosphate dehydrogenase; 2-ME: 2mercaptocthanol; 6-PGD: 6-phosphogluconate dehydrogenase; GSSG: oxidized glutathione; GSH: reduced glutathione.

${ }^{2}$ No enzyme stabilizing agents added.

${ }^{3}$ Statistical significance compared to normal (Student's $t$-test); $P<0.005$.

${ }^{4} P<0.01$.

${ }^{5} P<0.025$

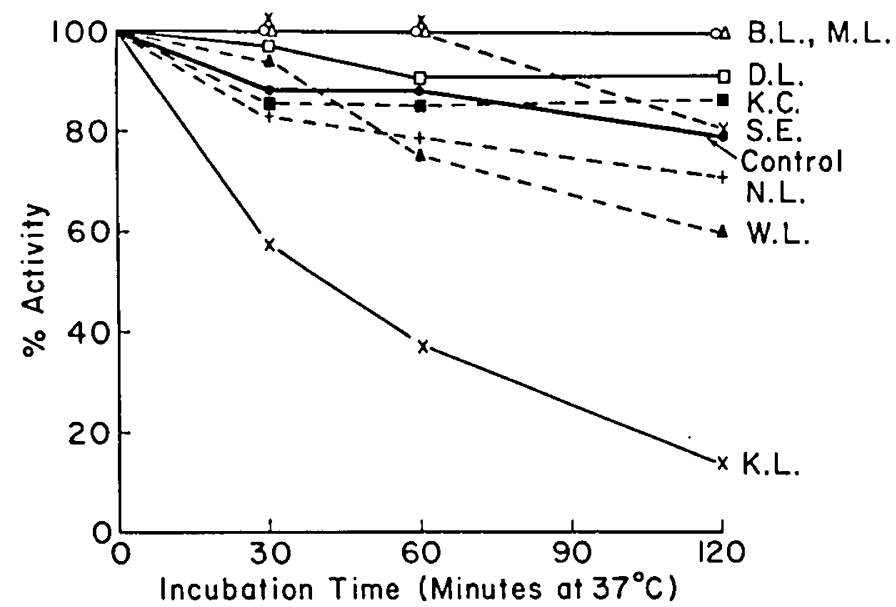

Fig. 2. Leukocyte glucose-6-phosphate dehydrogenase lability of patient $(K L)$ and her immediate family.

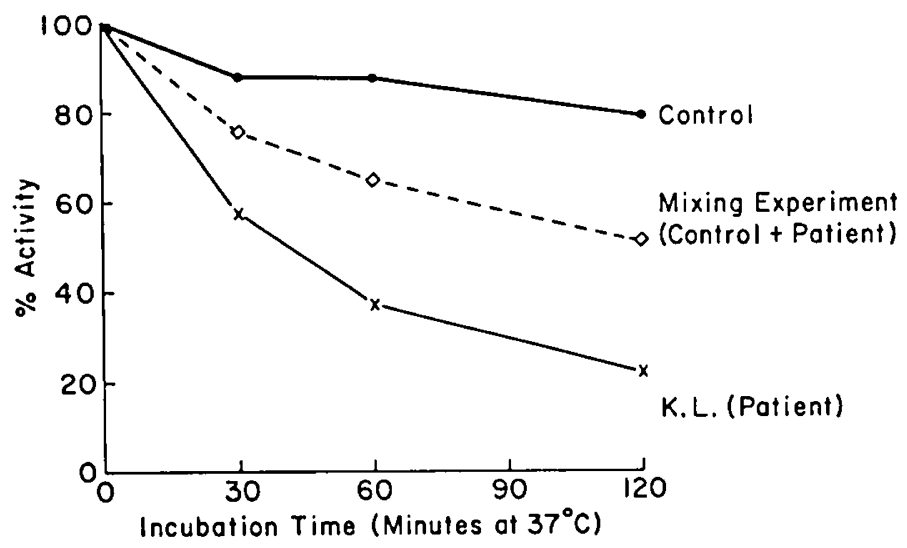

Fig. 3. Leukocyte glucose-6-phosphate dehydrogenase mixing experiment.

glutathione peroxidase was first described in females with CGD (18), and subsequently in a male child with this syndrome (24). In contrast to the present studies, however, a lability of G-6-PD was not detected. Another two patients with CGD have been shown to have deficient leukocyte superoxide production (13). The importance of the superoxide radical is that it can be bactericidal itself, or it may be further reduced to $\mathrm{H}_{2} \mathrm{O}_{2}$. The $\mathrm{H}_{2} \mathrm{O}_{2}$ formed may react with additional molecules of superoxide to

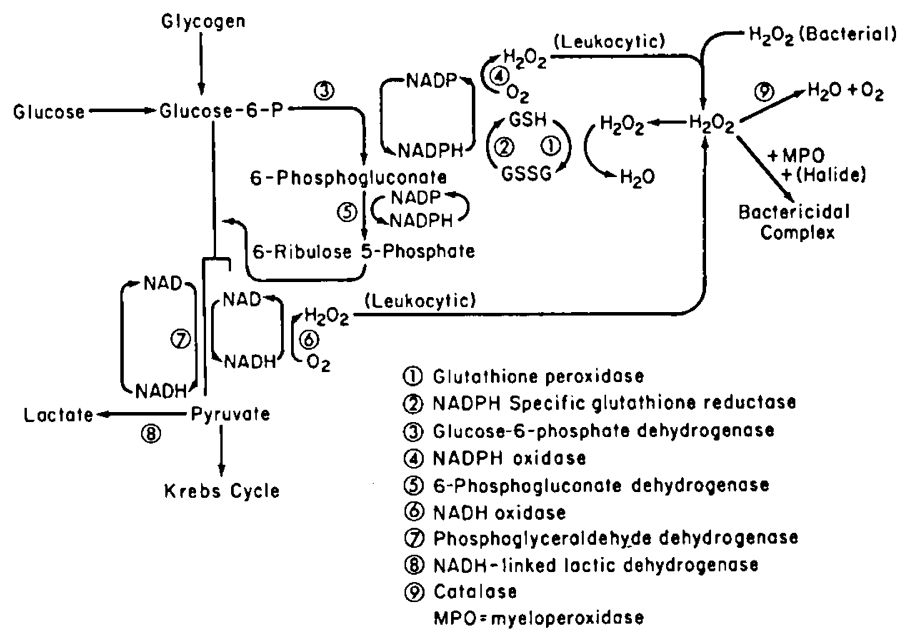

Fig. 4. Leukocyte enzyme biochemistry.

form hydroxyl radicals or may participate in the production of bactericidal aldehydes (32). An iodination defect has also been described in the leukocytes of patients with CGD (21).

In the present studies the labile G-6-PD enzyme in the leukocytes of the two male siblings could be stabilized by the addition of NADP and 2-ME, indicating the importance of this cofactor and of sulfhydral linkages in stabilization. The patient's G-6-PD was so severly labile, however, that stabilization was not possible even with the use of both of these agents (Fig. 1). The leukocyte G-6-PD lability in this family could be explained by the reduced content of leukocyte NADP, a deficiency of stabilizing factors, or an altered NADP to NADPH ratio as suggested by the studies of Erickson et al. (15). This is consistent with the findings of Yoshida (35), which indicate that monomeric G-6-PD is linked together by a molecule of NADP, forming an active dimer.

Abnormalities in the glutathione system were also detected in this kindred (Fig. 1, Table 3). The finding of diminished activity of glutathione peroxidase is of interest because of the data of Strauss et al. (33). These authors have suggested a primary role for the glutathione system in initiating the biochemical cascade resulting in the marked increase in $\mathrm{HMP}$ activity and $\mathrm{H}_{2} \mathrm{O}_{2}$ production necessary for normal bactericidal activity. The deficiency in NADPH-specific glutathione reductase detected in the two male siblings with G-6-PD lability and in both parents further differentiates this particular syndrome of neutrophil dysfunction from the classic X-linked form in which an elevated activity of leukocyte glutathione reductase was reported (18). 
In the framework of the schema proposed by Klebanoff $(20)$, depicting the inter-relationships of the leukocyte enzymes (Fig. 4), three recent communications help to elucidate the pathogenetic mechanisms involved in this kindred's disorder.

On the basis of results obtained using a granulocyte-free system in which xanthine oxidase is substituted for NADPH oxidase, Curnutte et al. (11) speculated that the bulk of the oxidation that occurs when NADPH, granulocyte particles, and manganese are incubated together takes place via a nonenzymatic free radical chain reaction. They concluded that the function of NADPH oxidase would be to generate the superoxide radical necessary to initiate this reaction. These results are pertinent in that these authors have previously reported (12) a defect in the pyridine nucleotide dependent production of superoxide in the leukocytes of three patients with X-linked CGD. They favored NADPH oxidase as the defective enzyme in these patients. Hohn and Lehrer (16) have demonstrated that the activity of NADPH oxidase in polymorphonuclear leukocytes from patients with CGD was $8 \%$ of normal. These authors concluded that the absence of a cyanide-insensitive NADPH oxidase or a deficiency in its activation is the primary metabolic defect in the X-linked CGD syndrome. Our data is consistent with both of these findings in that a deficiency in the NADPH oxidase system could result in reduced leukocyte NADP content and the G-6-PD lability. Since NADP is a regulator of HMP activity (5), its unavailability would inhibit the direct oxidation of glucose through the HMP either directly, or secondarily by inactivation of G-6-PD, accounting for the well known decreased HMP activity in CGD leukocytes $(3,17)$. It is tempting to speculate that a defect in the NADP generating system could also be related to the decreased activity of glutathione peroxidase, since this enzyme requires $\mathrm{H}_{2} \mathrm{O}_{22}$ as a substrate (Fig. 4). Thus, a defect in the NADPH oxidase system could not only account for our biochemical findings, but also the inability of the leukocytes to produce $\mathrm{H}_{2} \mathrm{O}_{22}$ superoxide, thereby causing a defect in their bactericidal function.

Although the affected male members of this family have not had fulminant bacterial infections, we feel that their clinical manifestations are compatible with the courses of patients previously described $(8,25)$ who have manifested a milder clinical form of CGD. The heterozygosity demonstrated in this kindred is consistent with an autosomal recessive mode of transmission. The patient, who manifests the most severe clinical illness, would be homozygous; the unaffected male sibling, $M D$, and the parents, $N L$ and $W L$, would be unaffected carriers of the gene; and the other two male siblings, $D L$ and $B L$, would be heterozygotes with an intermediate form of expression accounting for both their mild clinical findings, their impaired NBT dye reduction, and decreased bactericidal activity. The study of this kindred has provided further evidence that CGD represents a spectrum of leukocyte enzyme abnormalities and has implicated G-6-PD lability and the NADP generating system as an etiologic factor in the neutrophil dysfunction of this kindred.

\section{CONCLUSION}

The activities of several leukocyte enzymes were found to be diminished in a female patient with $C G D$ and several members studied. A lability of leukocyte G-6-PD was observed in the patient and two affected male siblings. A deficiency in glutathione reductase was seen in the parents and the two affected brothers. Diminished glutathione peroxidase was observed in all of the immediate family members. The leukocyte NADP content was decreased in the proband, her father, and the two affected male children. These findings suggest an autosomal recessive mode of inheritance and provide further evidence for the heterogeneity of enzymatic defects of the kukocyte which underly the clinical syndrome of CGD.

\section{RI:FIERENCIES AND NOTIS}

1. Bachner, R. L.: The growth and development of our understanding of chronic granulomatous disease. In: J. A. Bellanti and D. H. Dayton: The Phager cytic Cell in Host Resistance. pp. 173-200 (Raven Press, New York, 1975). 2. Baehner, R. L., and Karnovsky, M. L.: Deficiency of reduced nicotinamideadenine dinucleotide oxidase in chronic granulomatous disease. Science, 162: $1277(1968)$.

3. Bachner, R. L., and Nathan, D. G.: Leucocyte oxidase, defective activity in chronic granulomatous discase. Science, 1.55: 835 (1967).

4. Bachner. R. L., and Nathan. D. G.: Ouantitative NB'T test in chronic granulomatous disease. N. Engl. J. Mled., 278: 971 (1968).

5. Beck. W. S.: Occurrence and control of the phosphogluconate oxidation pathway in normal and leukemic leucocytes. J. Biol. Chem., 232: 271 (19.58).

6. Bellanti, J. A. Cantz, B., and Schlegel, R. J.: Accelerated decay of glucose-6phosphate dehydrogenase in chronic granulomatous disease. Pediat. Res., 4: $405(1970)$

7. Bellanti, J. A., Cantz, B. E., Yang, M. C., von Thadden, H., and Schlegel, R. $\mathrm{J}$.: Biochemical changes in human polymorphonuclear leukocytes during maturation. In: J. A. Bellanti and D. L. Dayton: The Phagocytic Cell in Host Resistance, pp. 321-332 (Raven Press, New York, 1975).

8. Biggar. W. D., Buron, S., and Holmes. B.: Chronic granulomatous disease in an adult male: A proposed X-linked defect. J. Pediat.. 88: 63 (1976).

9. Bridges, R. A.. Berendes, H., and Good, R. A.: A fatal granulomatous disease of childhood: The clinical, pathological and laboratory features of a new syndrome. Amer. J. Dis. Child., 97: 387 (1959).

10. Carson, M. J., Chadwick. D. L., Brubaker, C. A., Cleland, R. S., and Landing, B. H.: Thirteen boys with progressive septic granulomatosis. Pediatrics, 35: $405(1965)$.

11. Curnutte, J. T., Karnovsky, M. L., and Babior, B. M.: Manganese dependent NADPH oxidation by granulecyte particles. J. Clin. Invest., 57: 1059 (1976).

12. Curnutte, J. T., Kipnes, R. S., and Babior, B. M.: Defect in pyridine nucleotide dependent superoxide production by a particulate fraction from the granulocytes of patients with chronic granulomatous discase. N. Fingl. J. Med., 293: 628 (1975).

13. Curnutte, J. T., Whitten, D. M., and Barbior. B. M.: Defective superoxide production by granulucytes from patients with chronic granulomatous disease. N. Engl. J. Mled., 29(): 593 (1974).

14. DeChatelet, L.. R.: Oxidative bactericidal mechanisms of polymorphonuclear leucocytes. J. Infect. Dis., 131: 295 (1975)

15. Erickson, R. P., Stites. D. P.. Fudenberg, H. H., and Epstein, C. J.: Altered levels of glucose-6-phosphate dehydrogenase stabilizing factors in X-linked chronic granulomatous disease. J. Lab. (lin. Mled.. 80: 644 (1972).

16. Hohn, D. C., and Lehrer, R. I.: NADPH oxidase deficiency in X-linked chronic granulumatous disease. J. Clin. Invest., 55: $7(17$ (1975).

17. Holmes. B., Page, A. R., and Good, R. A.: Stuclies of metabolic activity of keukocytes from patients with genetic abnormality of phagocytic function. J. Clin. Invest., $46: 1422(1967)$.

18. Holmes, B., Park, B. H., and Malawista, S. E.: Chronic gramulomatous disease in females: $A$ deficiency of leucocyte glutathione peroxidase. $N$. Engl. J. Med.. 283: 217 (1970).

19. Holmes, B., Quie, P. G., Windhorst, D. B., and Good, R. A.: Fatal granulomatous disease of childhood. Lancet, $i: 1225$ (1966).

20. Klebanoff, S. J.: Intraleukocyte microbicidal defects. Ann. Rev. Med., 22: 39 (1971).

21. Klebanoff, S. J., and White, C. R.: Iodination defect in the leukocytes of a paticnt with chronic gramulomatous disease of childhood. N. Engl. J. Ned., $280: 460(1964)$.

22. Klingenberg, M.: Triphosphopyridine nucleotide (IPN). In: H. U. Bergmeyer: Methods of Enzymatic Analysis, pp. 535-536 (Academic Press, New York, 1963).

23. Lowry, O. H., Roscbrough, N. J., Farr, A. L., and Randall, R. J.: Protein measurement with the Folin phenol reagent. J. Biol. Chem., 193: 265 (1951).

24. Matsuda, I., Oka, Y., Taniguchi, N., Furuyama, M., Kodama, S., Aroshima, S., and Matsuyama, T.: Leukocyte glutathione peroxidase deficiency with chronic granulomatous disease. J. Pediat., 88: 581 (1976).

25. Ochs, H. D.. and Igo, R. P.: The NIBT slide test: A simple screening method for detecting chronic granulomatous disease and female carriers. J. Pediat., 83: 77 (1973).

26. Paglia, D. E., and Valentine, IV. N.: Studies on the quantitative and qualitative characterization of erythrocyte glutathione peroxidase. J. Lab. Clin. Med., $70: 158(1967)$.

27. Park, B. H., and Good, R. A.: NBI test stimulated. lancet, ii: 616(1970).

28. Quie, P. G., Kaplan, E. L., Page, A. R., Gruskay, F. L.. and Mala vista, S. E.: Defective polymorphonuclear-leukocyte function and chronic granulomatous disease in two female children. N. Engl. J. Ned., 278: 976 (1968).

29. Quic, P. G., White, J. G., Holmes, B... and Good, R. A.: In vitro bactericidal capacity of human polymorphonuclear leukocytes: Diminished activity in chronic granulomatous disease. J. Clin. Invest., f6: 668 (1967).

30. Reed, P. W.: Glutathione and the hexose monophosphate shunt in phagocytizing and hydrogen peroxide-treated rat leukecytes. J. Biol. Chem., 244: $2459(1969)$.

31. Richterich, R.: Clinical Chemistry: Theory and Practice (S. Karger. Based, $1969)$.

32. Sbarra, A. J., Paul, B. B., and Jacobs, A. A.: Biochemical aspects of phangeytic cells as related to bactericidal function. J. Reticuloendothel. Soc., 11: 492 (1972).

33. Strauss, R. R., Paull, B. B., Jacobs, A. A.. and Sbarra, A. J.: The role of the phagocyte in host-parasite interactions. XIX. Leukocyte glutathione reductase and its involvement in phagocytosis. Arch. Biochem. Biophys., 135: $265(1969)$. 
34. Windhorst, 1) B Pare A R Holmes, B. Quic, P. G. and Good, R. A. The pattern of genetic transmission of the keukocyte defect in total granulomatous disease of childhood. J. Clin. Invest., 47: 1026 (1968).

35. Voshide, A and Hoagland, F. D). Jr. Active molecular unit and NADP of human glucose-6-phosphate dehydrogenase. Biochem. Biophys. Res. Commun. 40: $1167(1970)$

36. We wish to thank Frederick Bicheusen, General, MC and his staff at Walter Reed General llospital for allowing us to study his patient.

37. This research was supported by United States Army Medical Research and Development (ommand, Rescarch (ontract DA-49-139-MID-2633, and

Copyright 1977 International Pediatric Rescarch Foundation, Inc.
National Institutes of Health Training Grant HD)-(0)261. 38. Informed consent was obtained from all family members studied.

39. The present address of Dr. WV. D. Rutenberg is: Department of Pediatrics. Harvard Medical School, Children's Hospital Medical Cinter, Boston. Mass.

41). Recunests for teprints should be addreseed to: J. A. Bellanti. M.D.. Georgetown University School of Nedicine, 3800 Reservioir Rd., N.W. Washingtom. D.C. 20007 (USA)

41. Received for publication June 4, 1976

42. Accepted for publication August 17, 1976.

Pediat. Res. 11:163-167 (1977)

Albumin difference spectroscopy

bilirubin erythrocytes

\title{
Influence of Intravenous Nutrients on Bilirubin Transport. I. Amino Acid Solutions
}

\author{
RICHARI) P. WIENEBERG ANI) M. MICHALI THALIR'H

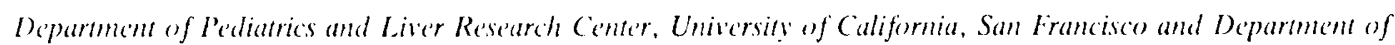 \\ I'ediatrics, University of Califormia, Davis, Califormia, USA
}

\section{Summary}

The effects of synthetic amino acids on bilirubin transport were investigated with competitive binding assays, peroxidase assays, isotopic studies of bilirubin uptake by red cells, and difference spectroscopy. Results indicated that amino acids had no significant effect on the distribution of bilirubin at pigment to albumin molar ratios likely to be encountered in clinical situations.

\section{Speculation}

Amino acids in solution do not appear to interfere with bilirubin transport. Parenteral alimentation with amino acids should be a safe procedure in jaundiced patients.

Parenteral feeding is frequenty required in premature and sick newborn infants who are unable to take adequate nutrition by mouth. The past decade has hrought technical advances which make it possible to supply not only carbohydrate but also fat and amino acids by an intravenous route. By these means. sustained growth has been achicved in both premature and term infants $(2,3)$.

Unconjugated hyperbilirubinemia is freguently present in sick newboms receiving high concentrations of amino acids and/or lipids. Since the possibility of kernicterus is known to be increased by therapeutic agents which interfere with binding of bilirubin to plasma albumin $(7,11)$, it is important to evaluate the effect of parenteral nutrient solutions on bitirubin transport. This study evaluates the influence of a commercially available synthetic amino acid solution on bilirubin binding to human scrum albumin and red blood cells.

\section{MATERIALS AND ME:THODS}

A stock $8 \%$ solution of amino acids in electrolyte medium (Veinamine, Cutter Laboratories, Inc., Berkeley, California) was used in all experiments. This preparation contains all essentaal amino acids and a balanced mixture of nonessential amino acids (Table 1). Glycinc is a principal constituent $(3.4 \mathrm{~g} / 100 \mathrm{ml})$. The osmolality of the stock solution is approximately 932 mosm/liter.

Bilirubin-human albumin solutions were prepared by dissolving bilirubin (Sigma) in $0.5 \mathrm{~N} \mathrm{NaOH}$ and adding the bilirubin to albumin (crystalline. Culter) dissolved in $0.055 \mathrm{~N}$ phosphate buffer, pH 7.4, ionic strength 0.15 . All bilirubin solutions were prepared and maintained in the dark or subdued light. Final pH of bilirubin-albumin solutions was 7.4 .

The interaction of amino acids with bilirubin-albumin complexes and transport were studied by competitive binding assays using cholestyramine and Sephadex gel filtration. the peroxidase assay, red cell uptake of radioactive bilirubin, and by an analysis of absorption spectra.

\section{(HOLESTYRAMINLE BINDING}

Competitive binding between albumin and cholestyramino (12) was studicd using at procedure modified from Schmided al. (10). Bilirubin-albumin solutions were prepared io contain $5 \mathrm{~g} /$ 100 $\mathrm{ml}$ human serum albumin; biliruhin/albumin molar ratios of $0.5,1.0,2.0$; and amino acid concentrations of $0,0.80$, and 2.67 g/100ml. An equal volume of prewashed cholestyramine (12) suspension was added and the misture was stirred constantly. Aliquots were removed at $0,15,30$. 60 , and 90 min of exposure and filtered free of resin through glass wool. The concentration of bilirubin remaining in individual filtrates was detemined by the method of Malloy and Evelyn (o). Control experiments in 